\title{
Biomarkers of Freshwater Algae Lemna minor as a Model for Urban Pollution with Pesticides and Heavy Metals
}

\author{
Khaled Y. Abdel-Halim ${ }^{1}$
}

\begin{abstract}
Biochemical changes in collected algal cells of Lemna minor were examined as biomarkers for pesticides and heavy metals pollution for different sites of an urban district. Four contaminated sites were chosen for the biomonitoring programs, while another site (rural zone) was considered as a reference to compare the risk factors. Aspartate aminotransferase (AST) reached the lowest values in winter season to account for $3.22,6.75,5.43$ and 2.35 U. $\mathrm{L}^{-1}$ in Potato International Center (PIC)(S1), EINasaria (S2), Kafr Hashaad (S3) and Bounfer (S4), respectively. Multiresidue of pesticides and potential toxic metals were examined in linear regression analysis with some biochemical components in algal cells. During the same season, the activity of alanine aminotransferase (ALT) showed decrease only in S3 and S4, but recorded the highest value $\left(10.00 \mathrm{U} . \mathrm{L}^{-1}\right)$ in $\mathrm{S2}$.

Carbohydrates and total protein levels were significantly decreased in all sites compared with reference. The algal pigments reached the lowest values in S1 to account for $4.76,1.83$, and $1.97 \mathrm{mg}^{-1}$ for chlorophyll a, b and carotenoides, respectively. Therefore, this study showed the importance of freshwater algae in biomonitoring programs especially for the urban regions.
\end{abstract}

\section{INTRODUCTION}

Biomarker studies are applied in the field (biomonitoring) because they provide an integrated view on how organisms are affected by the bioavailable fraction of the pollution present in the around media (Contardo-Jara and Wiegand, 2008). Biomonitoring can be conducted by sampling organisms living in the investigated areas (passive biomonitoring) or by exposure of organisms from either reference site or laboratorial culture to the investigated area (active biomonitoring) (Franzle, 2006).

Aquatic ecosystems can be considered as final sinks for many environmental contaminants. Practically, watercourses of urban areas are affected by high inputs of mixtures of organic and inorganic compounds from various sources, such as domestic and industrial sewage waters, abrasion from

streets and vehicles (Papiri et al,. 2003; Mahler et al., 2005; van Metre and Mahler, 2005). Generally, industrial influents cause significant distribution especially in aquatic media and their biota (Longston, 1990; Claisse and Alzieu, 1993). In addition, certain kinds of contaminants such as pesticides and heavy metals are considered the main industrial effluents introduced into water around urban communities (Akcali and Kucuksezgin, 2011).

Consequently, only the species showing some tolerance against pollution can establish sustainable populations. Biomarker research has already focused to find sensitive organisms and specific physiological reactions to detect low pollution levels in the aquatic system (Hallare et al., 2005). The use of freshwater organisms as bioindicators for pesticides and heavy metals pollution is currently very common. Algae and mollusks are considered suitable sentinel animals for this purpose (Rainbow, 1995). In addition, microalgae have ecological significance as a result of their position at the base of the aquatic food webs. Those attribute the microalgae to be used as sentinel organisms in environmental studies in order to evaluate the toxicity of various chemicals or pollution discharges, and particularly inputs of metals (Wei et al., 2006; Labra et al., 2007; Liebig et al., 2008). This group (algae, Lemna minor) is smallest flowering plants in the world which grow in foliage cover on freshwater bonds or streams. Sometimes, it is called lesser duckweed. Ducks and some fish species consume it as well as muskrat, beaver, birds and frogs. Environmental scientists use duckweeds to remove unwanted substances from water or assessing their toxicity. For this study, it was used as a bioindicator for aquatic pollution with pesticides and heavy metals in Kafr El-Zayat district resulting from industrial emission and discharge.

\section{MATERIALS AND METHODS}

\section{Description of the study area}

Kafr El-Zayat region, El-Gharbia governorate, Egypt was selected for this study as an urban model. It is considered as one of the main region due to the fact that, a number of large factories are established in it, especially chemical industries. Ecosystem around this region has an extensive exposure to chemical influents (Abdel-Halim et al., 2013).

\footnotetext{
${ }^{1}$ Mammalian \& Aquatic Toxicology Department,

Central Agricultural Pesticides Laboratory,

Ministry of Agriculture, Dokki, 12611, Giza, Egypt

Email address: khaled_yassen68@yahoo.com

Received May5, 2014, Accepted June15, 2014
} 
Algae, L. minor (family; Lemnaceae) was used as a bioindicator for urban pollution of freshwater bonds. Algae were seasonally collected during 2012-2013 from four locations as illustrated in figure 1. The samples were transferred to the laboratory, cleaned up and stored at $-20{ }^{\circ} \mathrm{C}$ until used. The chosen sites were as follows: S1, Potato International Center (PIC), S2 (Kafr El- Nasriyyah) and S3 (Kafr Hashaad) are near the brick factories. Site 4 (Binufar village) is near the pesticide and fertilizer factories. In addition, S5 (rural zone) was selected as a reference to compare the risk factors.

\section{Chemical analysis}

\subsection{Pesticide residues.}

Five $\mathrm{g}$ of algal tissues were homogenized using a polytron homogenizer (Janke\&Kunkel, Gmb $\mathrm{Hu} \mathrm{Co}$ $\mathrm{KG}$ ) for $1 \mathrm{~min}$. The suspension was mixed with $10 \mathrm{ml}$ of acetonitrile and shaken for $1 \mathrm{~min}$. One $\mathrm{g}$ of $\mathrm{NaCl}$ and $4 \mathrm{~g}$ of $\mathrm{MgSO}_{4}$ were added, vortexed immediately for 1 $\mathrm{min}$ and centrifuged at $4000 \mathrm{rpm}$ for $10 \mathrm{~min}$. An aliquot $(1 \mathrm{ml})$ was placed into a micro centrifuge tube $(2 \mathrm{ml})$ containing $50 \mathrm{mg}$ primary-secondary amine (PSA) and

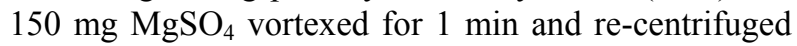
at $6000 \mathrm{xg}$ for $10 \mathrm{~min}$. The supernatant was checked on gas chromatography (Jiang et al., 2009). The analysis was carried out using gas chromatograph (Agilent 7890) equipped with electron capture detector (ECD) and HP-5MS capillary column $(30 \mathrm{~m} \times 0.25 \mathrm{~mm}$ i.d. with $0.25 \mu \mathrm{m}$ film thickness). The oven temperature was programmed from an initial temperature of $80{ }^{\circ} \mathrm{C}(2 \mathrm{~min}$ hold) to $260{ }^{\circ} \mathrm{C}$ at a rate of $5{ }^{\circ} \mathrm{C}$. $\mathrm{min}^{-1}$, while injector and detector temperature were maintained at 300 and $320{ }^{\circ} \mathrm{C}$, respectively. Nitrogen was used as a carrier gas at flow rate of $3 \mathrm{ml}$. $\mathrm{min}^{-1}$. DB-17 capillary column was applied as a confirmatory procedure.

Methods and instruments were fully validated as part of a laboratory quality assurances system (ISO/IEC, 1990). The Codex Committee's Criteria for quality assurance were followed to determine the performance of the multi-residue method. Recovery, accuracy, and limit of detection (LOD) were determined for every compound.

\subsection{Heavy metals quantification.}

Half g of dry algae was digested with perchloric: nitric acid $(1: 4 \mathrm{v} / \mathrm{v})$ to constant volume. After cooling, the samples were filtered and made up to the final volume of $25 \mathrm{ml}$ using deionized water (Akhbar Jan et al., 2010). Potential toxic metals $\mathrm{Cr}, \mathrm{Pb}, \mathrm{Cd}$ and $\mathrm{Ni}$ were examined on wavelengths $357.9,217,228.8$, and $232 \mathrm{~nm}$, respectively, in duplicates by using atomic absorption spectrometer (Spectra AA 220; Variance) at the department of water and soil (Alexandria University, Egypt). The concentration of each metal was calculated as mg. $\mathrm{kg}^{-1}$ dry weight and LOD was calculated as double the standard deviation of a series of measurements. All measurements were closed to the blank absorbance measurement (USEPA, 1983).

Appropriate quality assurance procedures and precautions were carried out to ensure reliability of the results. The samples were carefully handled to avoid contamination. Deionized water was used throughout the study.

\subsection{Biochemical quantification.}

\subsubsection{Plant pigments.}

Chlorophyll a, b and carotenoids were determined in algal suspension according to the method of Moran and Porath, (1980) by using N, N-dimethylformamide as an extraction solution. The absorbance was measured at 662, 644 and $440 \mathrm{~nm}$ for chlorophyll a, b and carotenoids, respectively, by using spectrophotometer (JENWAY 6305 UV/VIS). The pigment's concentrations were estimated as follows: chlorophyll a $=9.784 \times$ E.662-0.99 $\times$ E.644; chlorophyll $b=21.426 \times$ E.644-4.65 $\times$ E.662 and carotenoides $=4.695 \times$ E.440$0.268 \times($ chl. a + chl. b), respectively. The concentration was expressed as $\mathrm{mg} . \mathrm{L}^{-1}$.

\subsubsection{Total carbohydrate.}

After pigments extraction, the algal cells were extracted with $1 \mathrm{~N} \mathrm{NaOH}$ in a boiling water bath for $2 \mathrm{hr}$. The final extract was used for protein and carbohydrate quantification (Payne and Stewart, 1955). Total carbohydrate was determined as glucose by the method of Dubois et al. (1956).

\subsubsection{Total soluble protein.}

The protein content was determined according to the method of Lowry et al., (1951).

\subsubsection{Aspartate aminotransferase (AST) \& Alanine aminotransferase (ALT)}

The algal cells were washed several times and suspended in $60 \mathrm{ml}$ of $100 \mathrm{mM}$ of Tris $\mathrm{HCl}$ buffer, $\mathrm{PH}$ 7.6 containing $1 \mathrm{mM}$ EDTA and $6 \mathrm{mM}$ mercaptoethanol. The all were sonnicated for a total of $10 \mathrm{~min}(1 \mathrm{~min}$ each) and centrifuged at $20000 \mathrm{xg}$ for $20 \mathrm{~min}$. The supernatant was subjected to ammonium sulphate precipitation (between 35 and $65 \%$ ). The protein was dissolved in $20 \mathrm{mM}$ of the pervious buffer. All procedures were carried out at $4{ }^{\circ} \mathrm{C}$ (Ohmori et al., 1988). The activities were measured according to the method of Gello et al., (1985) by using pyridoxal phosphate reagent against blank at $340 \mathrm{~nm}$. The activity was expressed as U. $\mathrm{L}^{-1}$. 


\subsection{Statistical analysis.}

All the data were presented as a mean value $\pm \mathrm{SE}$ and subjected to analysis of variance (ANOVA). In addition, the means were compared for significance by Lethal Significant Difference (LSD) at 0.05. The regression coefficient (RC) between biochemical activities and pollutants concentration was estimated. The statistical analysis was performed using the Costat program (Cohort Software Inc, 1985).

\section{RESULTS AND DISCUSSION}

\section{Chemicals quantification.}

The residue levels of both pesticides and heavy metals in algal cells were quantified as presented in Table 1. The maximum residue levels were 1893.33, 1811.03, 663.31, 501.42 and $176.98 \mu \mathrm{g} . \mathrm{Kg}^{-1}$ wet mass for permethrin, deltamethrin, $\gamma$-BHC, $\alpha$-BHC and HCB, respectively. On the other hand, $P, P^{\prime}$-DDE, heptachlor, $P, P^{\prime}$-DDD showed the lowest seasonal means to be $0.34,0.41$ and $0.63 \mu \mathrm{g} . \mathrm{Kg}^{-1}$ wet mass, respectively. Among heavy metals levels, $\mathrm{Cr}$ and $\mathrm{Ni}$ recorded the maximum values 67.66 and $54.12 \mathrm{mg}$. $\mathrm{Kg}^{-1}$ dry weight, respectively. However, the lowest mean was recorded for $\mathrm{Cd}$ (1.71 mg. $\mathrm{Kg}^{-1}$ dry weight). The limits of detection and percentages of recovery were showed in Table 2.

\section{Biochemical quantification}

\subsubsection{Plant pigments.}

The pigments in algal cells e.g. chlorophyll a, b, and carotenoids were measured and illustrated in figure 2. The locational mean of chlorophyll a content reached the lowest value $\left(4.76 \mathrm{mg}\right.$. $\left.\mathrm{L}^{-1}\right)$ in $\mathrm{S} 1$ compared with $\mathrm{S} 5$ which not exceeded than $6.78 \mathrm{mg}$. $\mathrm{L}^{-1}$. However, chlorophyll b content reached this value $\left(1.68 \mathrm{mg}^{-1} \mathrm{~L}^{-1}\right)$ in S2 followed by S1 which accounted for $\left(1.83 \mathrm{mg} . \mathrm{L}^{-1}\right)$. Among carotenoids, the ascending order was as follows: $\mathrm{S} 5>\mathrm{S} 4>\mathrm{S} 2>\mathrm{S} 3>\mathrm{S} 1$, respectively.

\subsubsection{Total carbohydrates.}

Total carbohydrates were determined colorimetrically in algal cells as illustrated in figure $3 \mathrm{a}$. The carbohydrates levels reached the highest value during autumn season in S1 $\left(0.51 \mathrm{mg}\right.$. $\left.\mathrm{L}^{-1}\right)$. However, the locational mean showed the lowest value $(0.23 \mathrm{mg}$. $\mathrm{L}^{-1}$ ) in S4 compared with S5 which not exceeded than $1.11 \mathrm{mg}$. $\mathrm{L}^{-1}$. Among seasonal mean, the lowest value was $0.24 \mathrm{mg}$. $\mathrm{L}^{-1}$ during summer season.

\subsubsection{Total protein.}

The protein levels were determined in algal cells as illustrated in figure $3 \mathrm{~b}$. The protein levels decreased in most sites, where S2 observed the lowest values (2.02 $\mathrm{mg}$. $\mathrm{L}^{-1}$ ) during autumn season. In addition, locational mean reached the highest value $\left(1.46 \mathrm{mg}^{-1} \mathrm{~L}^{-1}\right)$ in $\mathrm{S} 3$ followed by $\mathrm{S} 4$ which accounted for $1.33 \mathrm{mg}$. $\mathrm{L}^{-1}$. No significant difference obtained in seasonal mean in all sites compared with reference which not exceeded than $1.14 \mathrm{mg}$. $\mathrm{L}^{-1}$.

\subsubsection{AST \& ALT.}

The enzymes activity was seasonally assayed in algal cells as illustrated in figure 4 . The activity of AST recorded the highest values in all sites during summer season. Moreover, S4 recorded the highest value (17.62 $\mathrm{U} . \mathrm{L}^{-1}$ ) in $\mathrm{S} 2$, while the lowest value observed in S1 to account for $7.63 \mathrm{U}$. L $\mathrm{L}^{-1}$. However, ALT activity was lower than those of AST in most sites. Thus, the activity reached the highest value $20.08{\mathrm{U} . \mathrm{L}^{-1}}^{-1} \mathrm{~S} \mathrm{~S} 1$. Generally, the locational mean reached the highest value in $\mathrm{S} 1$ followed by $\mathrm{S} 2$ to account for 11.73 and $10.52 \mathrm{U}^{-1} \mathrm{~L}^{-1}$, respectively.

\section{Relationship between pollutants and algal biomarkers.}

To investigate this relation, a simple linear regression analysis of biomarker responses on metals concentrations was conducted in algal cells for seven different sites of Kafr El-Zayat district as illustrated in Table 3. The data showed that, potential toxic metals were in a positively relation with AST, while in positively relation with ALT. Among algal pigments, they were in negatively relation with all pigments. In case of pesticides, multi-linear regression analysis was conducted as illustrated in Table 4.

\section{DISCUSSION}

The present study investigated the impact of aquatic pollution along urban discharge of Kafr El-Zayat district on some biochemical components of freshwater algae L. minor. In this region, industrial discharge and urban wastes disposal into water are the major source of pollution to selected sites near emission sources. Practically, watercourse of urban areas are affected by high inputs of mixtures of organic and inorganic compounds from various sources such as domestic and industrial sewage water, abrasion from streets and vehicles (Papiri et al., 2003; Mahler et al., 2005; van Metre and Mahler, 2005). According to algal distribution in freshwater, uptake of unwanted substances, and easy to sample, the Lemna minor was selected as a bioindicator for aquatic pollution with pesticides and toxic heavy metals in Kafr El-Zayat district resulting from industrial effluents and urban discharge.

The obtained results showed that, seasonal residue levels of pesticides reached the highest values for $\Sigma \mathrm{BHC}$, aldrin, methoxychlor and heptachlor epoxide, respectively, and other group e.g. permethrin and deltamethrin. 
Table 1. Seasonal residue levels of pesticides and heavy metals in algal cells of Lemna minor.

\begin{tabular}{|c|c|c|c|c|c|c|}
\hline \multirow[t]{2}{*}{ compound } & $\min$ & $\max$ & mean & $\mathbf{n}$ & variance & Stdev \\
\hline & \multicolumn{6}{|c|}{ pesticides ( $\mu \mathrm{g} . \mathrm{kg}^{-1}$ wet mass) } \\
\hline$\alpha-\mathrm{BHC}$ & BDL & 501.42 & 59.21 & 20 & 19017.21 & 274.01 \\
\hline $\mathrm{HCB}$ & BDL & 176.98 & 28.34 & 20 & 2227.51 & 95.06 \\
\hline$\gamma-\mathrm{BHC}$ & BDL & 663.31 & 93.57 & 20 & 30972.92 & 359.01 \\
\hline$\beta-\mathrm{BHC}$ & BDL & 63.73 & 18.32 & 20 & 401.38 & 32.81 \\
\hline heptachlor & BDL & 5.75 & 0.41 & 20 & 3.21 & 1.90 \\
\hline aldrin & BDL & 156.63 & 14.03 & 20 & 1261.04 & 86.66 \\
\hline hept. epoxide & BDL & 100.61 & 11.78 & 20 & 510.18 & 55.00 \\
\hline$\gamma$-chlordane & BDL & 6.31 & 1.11 & 20 & 3.99 & 3.37 \\
\hline dieldrin & BDL & 59.02 & 5.53 & 20 & 191.90 & 32.59 \\
\hline P,P'-DDE & BDL & 5.36 & 0.34 & 20 & 3.00 & 1.54 \\
\hline endrin & BDL & 36.18 & 6.83 & 20 & 108.87 & 19.22 \\
\hline $\mathrm{P}, \mathrm{P}^{\prime}-\mathrm{DDD}$ & BDL & 6.33 & 0.63 & 20 & 3.54 & 3.49 \\
\hline P,P'-DDT & BDL & 66.22 & 9.19 & 20 & 410.49 & 35.88 \\
\hline methoxychlor & BDL & 115.43 & 13.53 & 20 & 920.76 & 30.34 \\
\hline cyhalothrin & $\mathrm{BDL}$ & 74.65 & 3.73 & 20 & 278.63 & 16.69 \\
\hline permethrin & BDL & 1893.33 & 94.67 & 20 & 17923.9 & 423.36 \\
\hline deltamethrin & BDL & 1811.03 & 629.14 & 20 & 6939987.0 & 2634.39 \\
\hline \multicolumn{7}{|c|}{ heavy metals (mg. kg ${ }^{-1}$ dry weight) } \\
\hline $\mathrm{Cd}$ & BDL & 16.23 & 1.71 & 20 & 15.06 & 8.91 \\
\hline $\mathrm{Pb}$ & BDL & 37.50 & 12.56 & 20 & 90.47 & 19.09 \\
\hline $\mathrm{Cr}$ & BDL & 67.66 & 7.29 & 20 & 317.85 & 37.26 \\
\hline $\mathrm{Ni}$ & BDL & 54.12 & 5.86 & 20 & 156.78 & 29.69 \\
\hline
\end{tabular}

$\mathrm{BDL}=$ below detection limit; $\mathrm{n}=$ number of samples.

Table 2. Recovery percentage and the minimum detection limits for various compounds

\begin{tabular}{lccc}
\hline \multicolumn{1}{c}{ compound } & \% recovery & SD & LOD (ng) \\
\hline$\alpha$-BHC & 97 & 4 & 0.02 \\
\hline $\mathrm{HCB}$ & 82 & 12 & 0.05 \\
\hline$\gamma$-BHC & 93 & 9 & 0.01 \\
\hline$\beta$-BHC & 95 & 5 & 0.04 \\
\hline heptachlor & 98 & 10 & 0.03 \\
\hline Aldrin & 92 & 8 & 0.01 \\
\hline hept. Epoxide & 100 & 8 & 0.03 \\
\hline$\gamma$-chloredane & 91 & 6 & 0.02 \\
\hline Dieldrin & 102 & 6 & 0.02 \\
\hline P,P'-DDE & 98 & 5 & 0.05 \\
\hline Endrin & 96 & 3 & 0.01 \\
\hline P,P'-DDD & 95 & 7 & 0.05 \\
\hline P,P-DDT & 99 & 10 & 0.05 \\
\hline methoxychlor & 91 & 10 & 0.02 \\
\hline cyhalothrin & 80 & 10 & 0.06 \\
\hline permethrin & 87 & 11 & 0.06 \\
\hline Fenvelerate & 89 & 8 & 0.06 \\
\hline deltamethrin & 94 & 9 & 0.06 \\
\hline Pb & 100.0 & 30 & 0.1 \\
\hline Cd & 77.0 & 3 & 0.02 \\
\hline Cr & 73.9 & 15 & 0.06 \\
\hline $\mathrm{Ni}$ & 81.3 & 20 & 0.1 \\
\hline D & & & \\
\hline
\end{tabular}

$\mathrm{SD}=$ standard deviation and $\mathrm{LOD}=$ limits of detection. 
Table 3. Simple linear regression analysis of biomarker responses (Y) on metals concentrations $(X)$ in algae from contaminated sites of Kafr El-Zayat region

\begin{tabular}{|c|c|c|c|c|c|c|c|}
\hline $\begin{array}{l}\text { Biomarker } \\
\text { response }(y)\end{array}$ & $\begin{array}{l}\text { Metal } \\
\quad(\mathbf{x})\end{array}$ & $\mathbf{r}$ & $\mathbf{r}^{2}$ & $d f$ & $F$ & $\begin{array}{l}\text { Intercept } \\
\text { (a) }\end{array}$ & $\begin{array}{l}\text { Regression } \\
\text { coefficient (b) }\end{array}$ \\
\hline AST & $\mathrm{Cr}$ & -0.375 & 0.141 & 1 & 0.33 & 12.959 & -0.239 \\
\hline $\mathrm{AST}$ & $\mathrm{Cd}$ & -0.381 & 0.145 & 1 & 0.34 & 12.927 & -1.017 \\
\hline AST & $\mathrm{Ni}$ & -0.284 & 0.081 & 1 & 0.18 & 12.814 & -0.226 \\
\hline AST & $\mathrm{Pb}$ & 0.678 & 0.460 & 1 & 1.70 & 3.43 & 0.678 \\
\hline ALT & $\mathrm{Cr}$ & 0.04 & 0.002 & 1 & 0.001 & 9.011 & 0.0059 \\
\hline ALT & $\mathrm{Cd}$ & 0.049 & 0.002 & 1 & 0.002 & 9.05 & 0.030 \\
\hline ALT & $\mathrm{Ni}$ & 0.026 & 0.001 & 1 & 0.001 & 9.018 & 0.0047 \\
\hline ALT & $\mathrm{Pb}$ & -0.127 & 0.016 & 1 & 0.030 & 9.397 & -0.0292 \\
\hline Total protein & $\mathrm{Cr}$ & -0.885 & 0.783 & 1 & 4.260 & 1.108 & -0.0029 \\
\hline Total protein & $\mathrm{Cd}$ & -0.832 & 0.692 & 1 & 4.510 & 1.108 & -0.0123 \\
\hline Total protein & $\mathrm{Ni}$ & -0.747 & 0.558 & 1 & 2.520 & 1.109 & -0.0033 \\
\hline Total protein & $\mathrm{Pb}$ & 0.581 & 0.338 & 1 & 1.020 & 1.053 & 0.0032 \\
\hline Carbohydrates & $\mathrm{Cr}$ & 0.779 & 0.607 & 1 & 3.080 & 0.398 & 0.0148 \\
\hline Carbohydrates & $\mathrm{Cd}$ & 0.786 & 0.618 & 1 & 3.220 & 0.397 & 0.0626 \\
\hline Carbohydrates & $\mathrm{Ni}$ & 0.669 & 0.448 & 1 & 1.910 & 0.390 & 0.0166 \\
\hline Carbohydrates & $\mathrm{Pb}$ & -0.592 & 0.350 & 1 & 1.080 & 0.690 & -0.0176 \\
\hline Chloro. a & $\mathrm{Cr}$ & -0.175 & 0.031 & 1 & 0.060 & 6.478 & -0.0466 \\
\hline Chloro. a & $\mathrm{Cd}$ & -0.175 & 0.031 & 1 & 0.050 & 6.444 & -0.176 \\
\hline Chloro. a & $\mathrm{Ni}$ & -0.283 & 0.080 & 1 & 0.170 & 6.708 & -0.0944 \\
\hline Chloro. a & $\mathrm{Pb}$ & -0.85 & 0.723 & 1 & 5.190 & 10.537 & -0.356 \\
\hline Chloro. b & $\mathrm{Cr}$ & -0.324 & 0.105 & 1 & 0.230 & 4.525 & -0.065 \\
\hline Chloro. b & $\mathrm{Cd}$ & -0.307 & 0.094 & 1 & 0.210 & 4.493 & -0.26 \\
\hline Chloro. b & $\mathrm{Ni}$ & -0.427 & 0.182 & 1 & 0.450 & 4.720 & -0.1077 \\
\hline Chloro. b & $\mathrm{Pb}$ & -0.812 & 0.659 & 1 & 3.88 & 7.287 & -0.257 \\
\hline Carotenoids & $\mathrm{Cr}$ & -0.186 & 0.035 & 1 & 0.07 & 2.996 & -0.0375 \\
\hline Carotenoids & $\mathrm{Cd}$ & -0.169 & 0.029 & 1 & 0.06 & 2.971 & -0.1428 \\
\hline Carotenoids & $\mathrm{Ni}$ & -0.282 & 0.080 & 1 & 0.17 & 3.156 & -0.0709 \\
\hline Carotenoids & $\mathrm{Pb}$ & -0.759 & 0.576 & 1 & 2.71 & 5.693 & -0.2396 \\
\hline
\end{tabular}

Regression follow the mod $\mathrm{y}=\mathrm{a}+\mathrm{bx}$ obtained by simple linear regression; $\mathrm{r}^{2}=$ coefficient of determination; $\mathrm{df}=\mathrm{degrees}$ of freedom value $=1$ means a simple linear regression of equation) and $\mathrm{F}=$ variation. 
Table 4. Multilinear regression analysis of biomarker responses (y) on pesticides concentration ( $x)$ in freshwater algae from seven different sites of Kafr El-Zayat district.

\begin{tabular}{|c|c|c|c|c|c|c|c|}
\hline \multirow[t]{2}{*}{ factors } & \multicolumn{7}{|c|}{ Biomarker responses $(y)$} \\
\hline & AST & ALT & TP & Carbohy. & $\begin{array}{l}\text { Chloro. } \\
\text { a }\end{array}$ & $\begin{array}{l}\text { Chloro. } \\
\text { b }\end{array}$ & Carotene. \\
\hline df & 18 & 18 & 18 & 18 & 18 & 18 & 18 \\
\hline $\mathrm{f}$ & $1.961 *$ & 0.0897 & 0.473 & $1.421 *$ & $7.912 * *$ & $4.527 *$ & $2.318 *$ \\
\hline $\mathrm{a}$ & 6.483 & 7.998 & 1.089 & 0.521 & 7.133 & 4.998 & 3.238 \\
\hline \multicolumn{8}{|c|}{ Pesticides concentration $(\mathrm{x})$} \\
\hline$\alpha-\mathrm{BHC}$ & -0.072 & 0.038 & -0.0008 & 0.0038 & 0.097 & 0.067 & 0.072 \\
\hline $\mathrm{HCB}$ & -0.052 & -0.142 & 0.0008 & -0.0024 & -0.296 & -0.217 & -0.232 \\
\hline$\gamma-\mathrm{BHC}$ & 0.122 & 0.036 & 0.0002 & -0.0018 & 0.023 & 0.017 & 0.025 \\
\hline$\beta-\mathrm{BHC}$ & 1.144 & 0.167 & 0.004 & -0.025 & -0.093 & -0.058 & -0.013 \\
\hline heptachlor & 3.989 & 3.280 & 0.0056 & -0.074 & 6.783 & 5.204 & 5.382 \\
\hline aldrin & -0.722 & -0.008 & -0.004 & 0.022 & 0.198 & 0.124 & 0.121 \\
\hline heptachlor Epoxide & 0.319 & -0.030 & 0.0011 & -0.006 & -0.257 & -0.196 & -0.178 \\
\hline$\gamma$-chlordane & 6.098 & 1.852 & 0.0019 & -0.135 & 2.14 & 1.711 & 1.938 \\
\hline dieldrin & -0.466 & -0.002 & 0.0046 & 0.024 & -0.0397 & -0.073 & -0.028 \\
\hline$P, P^{\prime}$-DDE & -12.028 & -7.639 & -0.015 & 0.195 & -13.746 & -10.472 & -11.154 \\
\hline endrin & 0.868 & 0.539 & -0.0018 & -0.00001 & 0.699 & 0.492 & 0.597 \\
\hline$P, P^{\prime}-\mathrm{DDD}$ & 2.122 & -1.163 & 0.018 & -0.085 & -3.489 & -2.542 & -2.589 \\
\hline$P, P^{\prime}$-DDT & -1.931 & -0.745 & -0.0018 & 0.023 & -0.748 & -0.541 & -0.688 \\
\hline methoxychlor & 0.606 & 0.103 & 0.0016 & -0.011 & -0.05 & -0.037 & -0.005 \\
\hline cyhalothrin & 1.100 & 0.514 & -0.0023 & 0.002 & -0.386 & 0.234 & 0.378 \\
\hline permthrin & -0.005 & 0.0002 & -0.0001 & 0.0006 & -0.006 & -0.006 & -0.004 \\
\hline deltamethrin & 0.004 & -0.0001 & 0.0001 & -0.0001 & -0.002 & -0.001 & -0.001 \\
\hline
\end{tabular}

Regression follow the mod $y=a+b x$ obtained by simple linear regression; $r^{2}=$ coefficient of determination; $d f=$ degrees of freedom value $=1$ means a simple linear regression of equation $)$ and $\mathrm{F}=$ variation $(*=$ means the significant at $0.05 ; * *=$ means the significant at 0.01 and $* * *=$ means the significant at 0.0001 ).
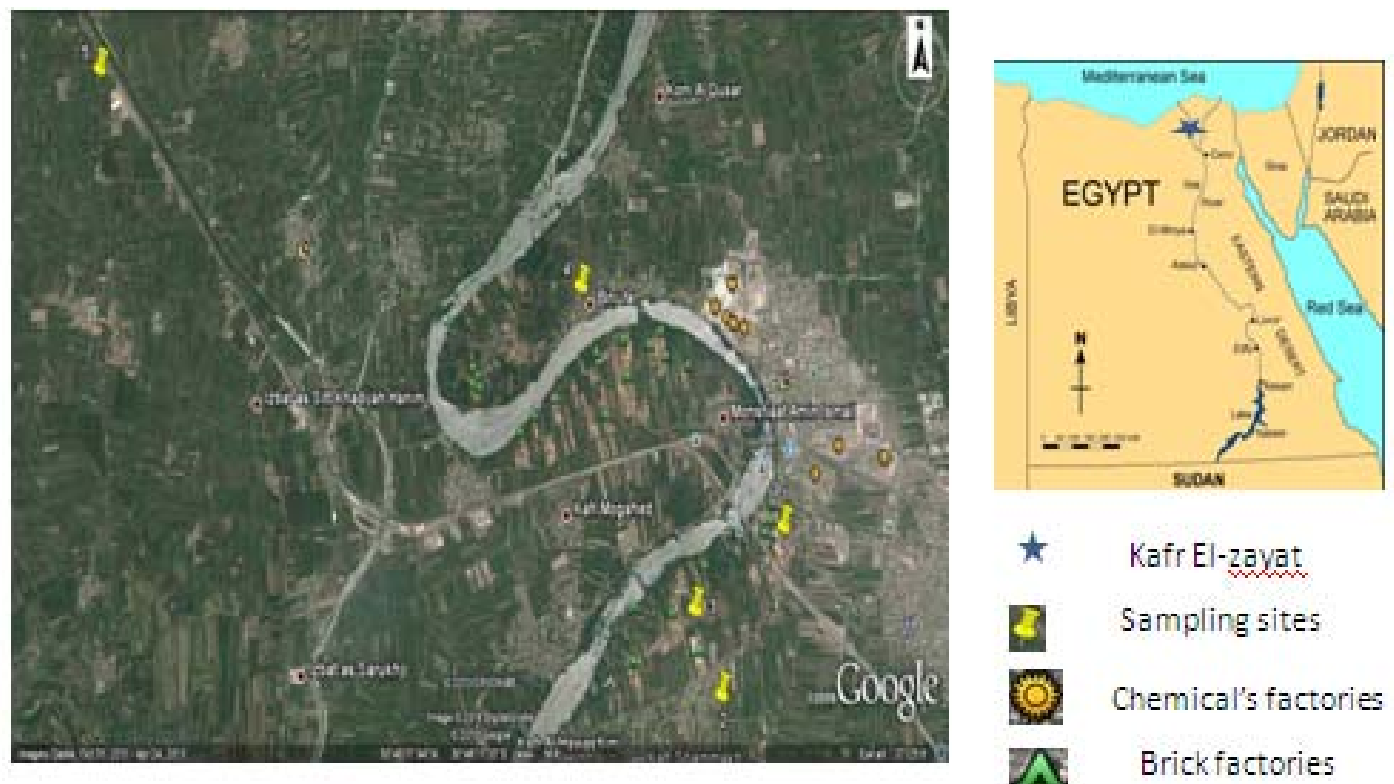

Figure1: Sampling sites and contaminants sources of Kafr El-Zayat city (http://earth.google.com). 


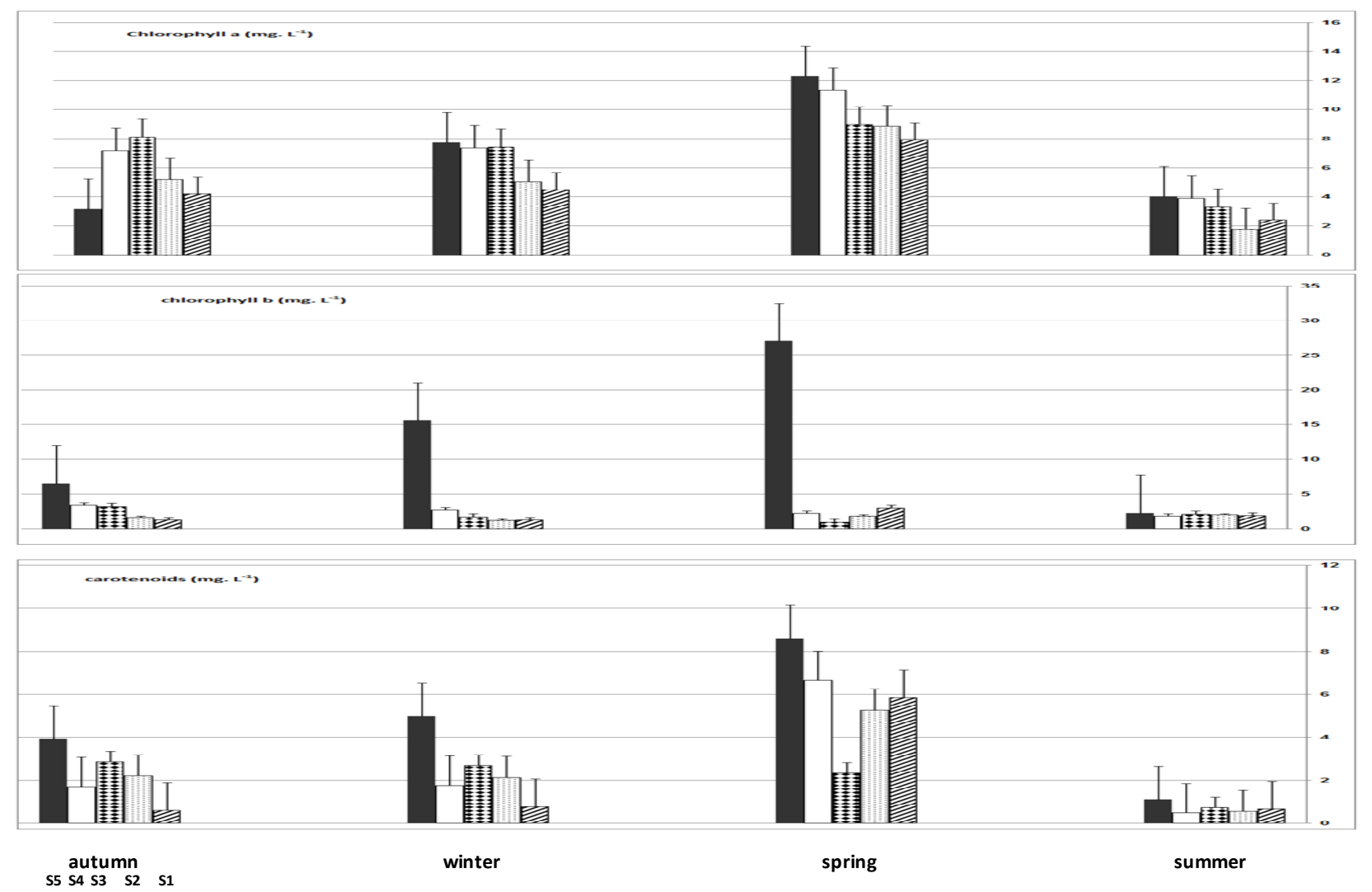

Figure 2. Alterations in algal pigments (2a) chlorophyll a; (2b) chlorophyll b; and (2c) carotenoids .Vertical bars indicate standard errors.

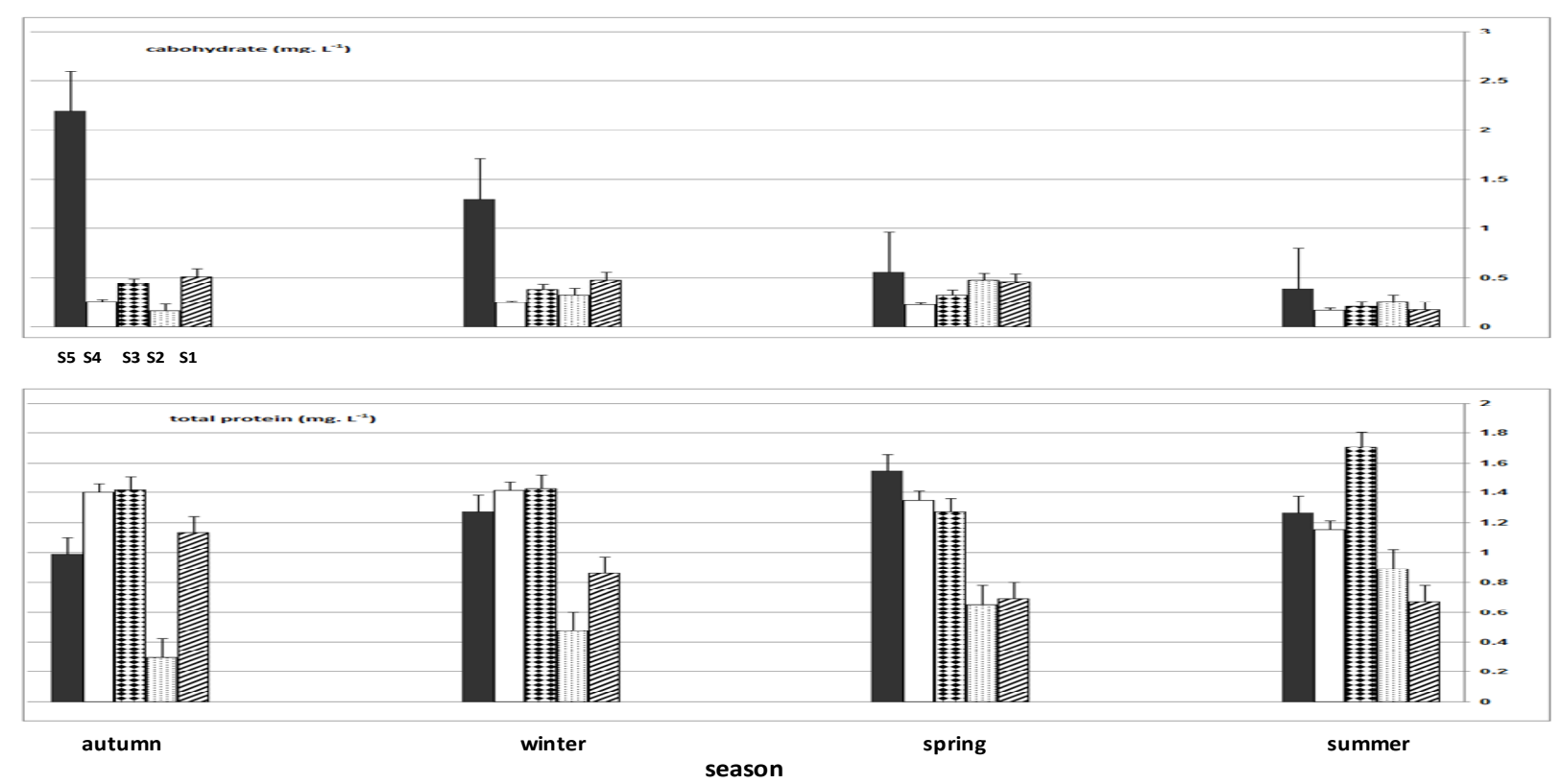

Figure 3. Alterations in biochemical components (3a) carbohydrate and (3b) total protein. Vertical bars indicate standard errors 

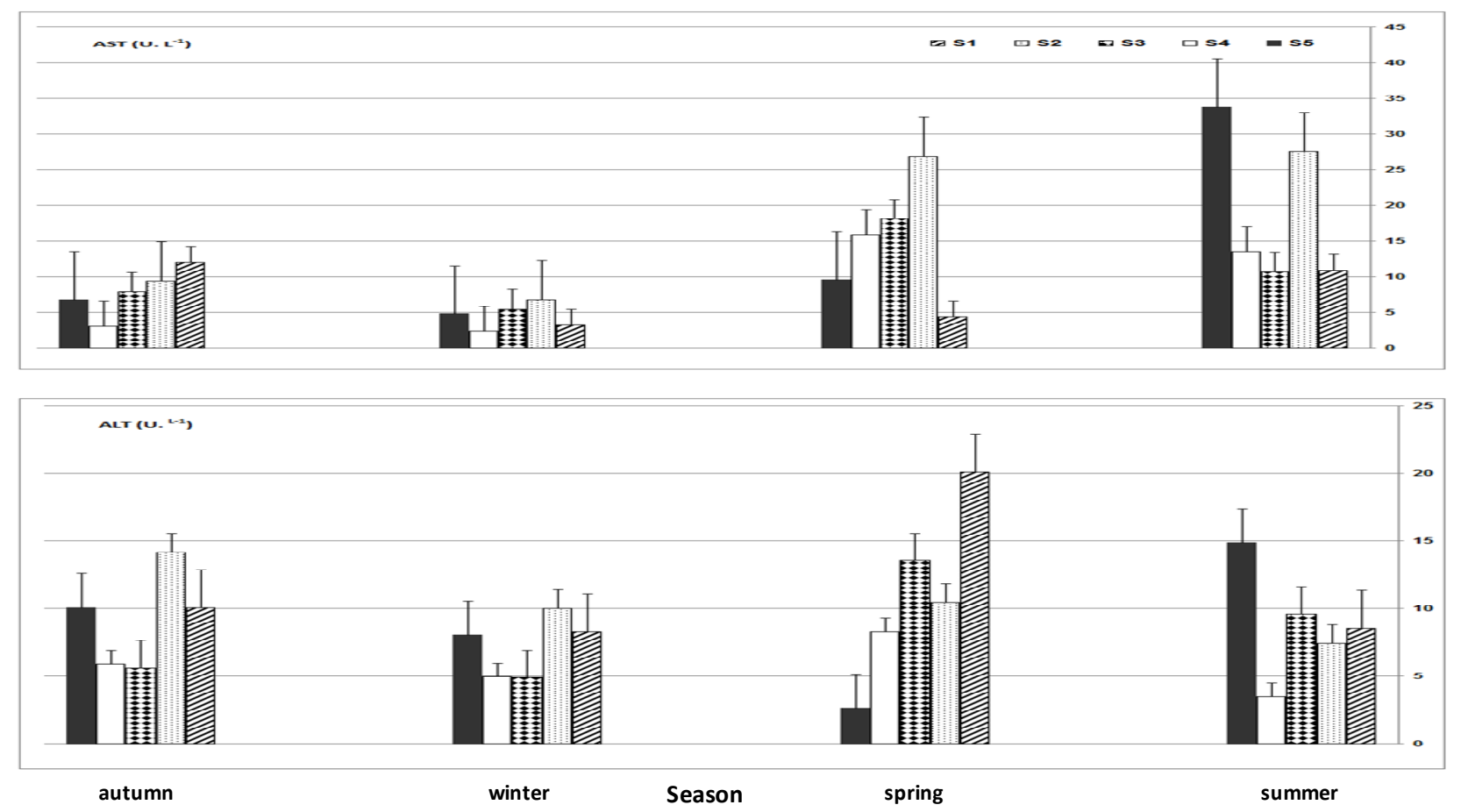

Figure 4. Alterations in enzymes (4a) AST and (4b) ALT. Vertical bars indicate standard errors.

Additionally, overuse or industrial emission of pesticides increases the probability of negative impacts on non-target organisms such as aquatic biota, terrestrial, plants, mammals and soil microorganisms (Tremolada et al., 2004).

On the other hand, $\mathrm{Pb}$ was detected in all seasons followed by Ni especially in S3 and S4 which are near brick or pesticides factories. The use of fuels in brick making factories is a major source of $\mathrm{Pb}$ and $\mathrm{Cd}$, while $\mathrm{Ni}$ is mostly emitted from fertilizers and chemical industries near the sites as presented in figure 1. In addition, different industries such as plant oils extraction, textile, fertilizers, acids, salts, pesticides and detergents are major source of $\mathrm{POP}_{\mathrm{s}}$ and heavy metals which are emitted in air. Another source is urban sewage water, where metals pollution has been associated with sewage outlets (Chen et al., 2005; Wannaz et al., 2006). The emission of these factories mostly precipitates on land and aquatic media such as streams and canals around them.

In worldwide, several studies investigated that, major source of air contamination is the non-ferrous metals industry which emits $\mathrm{Cd}, \mathrm{Pb}, \mathrm{Ni}, \mathrm{As}, \mathrm{Cu}, \mathrm{Se}$ and Zn (Liu et al., 2003; Lewtas, 2007; Blake et al., 2007). Fuels in factories is the major source of $\mathrm{Hg}, \mathrm{As}, \mathrm{Cr}$, and Se (Zhuang et al., 2004; Keegan et al., 2006; Guijian et al., 2007), while combustion of oil is the most important source of $\mathrm{Ni}$ and Vanadium (V)(US EPA, 2002c; Dundar, 2006).

Therefore, algae play an important role in the disposal, chemical transformation and bioaccumulation of many toxic compounds (Wang et al., 1998; Okay et al., 2000; Todd et al., 2002; Lei et al., 2002, 2007; Bopp and Lettieri, 2007). In addition, macro and microalgae also play an important role in the removal of polychlorinated biphenyls from the euphotic zone by direct sinking of the cells (Wang et al., 1998; Gerofke et al., 2005).

On the other hand, the movement of most $\mathrm{POP}_{\mathrm{s}}$ in the environment is a complex task due to the distribution and exchange dynamics of these compounds in different physical phases. In addition, the cycle of volatilization and deposition may be repeated many times with the result that $\mathrm{POP}_{\mathrm{s}}$ accumulate in an area far removed from where they initially used or emitted (Jones and Voogt, 1999). These concerns may link to the changes which done in the residue levels of $\mathrm{POP}_{\mathrm{s}}$ in biota of contaminated sites of this region.

The changes and interactions of pollutants with algal biochemical components have important consideration as biomarkers of urban pollution. As mentioned previously, the study of physiological and biochemical alterations as well as the identification and quantification of pollutants in organisms are essential diagnostic tools (Van Gestel and Van Brummelen, 
1996; Handy and Depledge, 1999; Handy et al., 2003). Additionally, photosynethyic organisms such as algae are early and timely indicators of potential hazard in aquatic systems and should be seriously considered in any environmental assessment program (Kowalewska, 1999; Okay et al., 2000). Many studies depending on organisms had been reported as regionally important tools in environmental programs e.g. fish in Australia, Asia and America (Edwards et al., 2001; Ueno et al., 2005; Carrasco-Letelier et al., 2006), land snails (Reogli et al., 2006; Radwan et al., 2010; Abdel-Halim et al., 2013), macroalgae (Fytianos et al., 1999; SanchezRodrignez et al., 2001; Conti and Cecchetti, 2003) and microalgae (Siripornadulsil et al., 2002; Nishikawa et al., 2003; Pinto et al., 2003; Tripathi et al., 2006). Moreover, biochemical responses of the organisms exposed to $\mathrm{POP}_{\mathrm{s}}, \mathrm{PAH}_{\mathrm{s}}$ and pesticides have been reported for the last two decades and documented by the international organizations such as Economic Corporation and Development (OECD) and the United States Environmental Protection Agency (USEPA) which recommended to use algae because of their wide distribution and their sensitivity with respect to the environmental evaluation of freshwater ecosystems (Bauer et al., 2012).

\section{CONCLUSION}

The obtained results of this study may provide information about the role of freshwater algae in biomonitoring of urban pollution with chemical contaminants. Algae; L. minor is considered a useful tool for diagnosis of aquatic system pollution, especially in urban regions. Biochemical components and enzymes of algae may be useful biomarkers to assess biomonitoring programs. Risk management programs must be done in this region for prevention ecosystem disruption and non-target organism's outcomes.

\section{ACKNOWLEDGMENT}

I am gratefully indebted to professor A. Abaas (soil\&water depart., Alexandria University) for helping in potential toxic metals analysis. Also, I wish to thank Dr H. Ashoush (Etay El-Baroud Research Station) for helping in samples collection and transportation.

\section{REFERENCES}

Abdel-Halim, A. Y., A. M. Abo El-Saad, M. M. Talha, A. A. Hussein, N. M. Bakry (2013). Oxidative stress on land snail Helix aspersa as a sentinel organism for ecotoxicological effects of urban pollution with heavy metals. Chemosphere 93, 1131-1138.

Akcali, I. and Kucuksezgin, F. (2011). A biomonitoring study: Heavy metals in macroalgae from estern Aegean coastal areas. Marine Pollut. Bull. 62, 637-646.

Akhbar Jan, F., Ishaq, M., Khan, S., Ihsanullah, I., Ahmed, I. and Shakirullah, M. (2010). A comparative study of human health risks via consumption of food crops grown on wastewater irrigated soil (Peshawar) and relatively clean water irrigated soil (Lower Dir). J. Hazardous Materials 612-621.

Bauer, D.E., Conforti, V., Ruiz, L., and Gomez, N. (2012). An in situ test to explore the responses of Scenedesmus acutus and Lepocinclis acus as indicators of the changes in water quality in lowland streams. Ecotoxicol. Environ. Safety 77, 71-78.

Blake, W.H., Walsh, R.P., Reed, J.M., Barnsley, M.J., and Smith, J. (2007). Impacts of landscape remediation on the heavy metal pollution dynamics of a lake surrounded by non-ferrous smelter waste. Environ. Pollut. 148, 268-280.

Bopp, S.K., and Lettieri, T., (2007). Gene regulation in the marine diatom (Thalassiosira pseudonana) upon exposure to polycyclic aromatic hydrocarbons $\left(\mathrm{PAH}_{\mathrm{s}}\right)$. Gene 396, 293-302.

Carrasco-Letelier, L., Eguren, G., Mello, F.T., and Groves, P., (2006). Preliminary field study of hepatic porphyrin profiles of (Astynax fasciatus) (Teleostei, Characiformes) to define anthropogenic pollution. Chemistry 62, 12451252.

Chen, T.B., Zheng, Y.M., Lei, M., Huang, Z.C., Wu, H.T., Chen, H., Fan, K.K., Yu, K., Wu, X., and Tian, Q.Z., (2005). Assessment of heavy metal pollution in surface soils of urban parks in Beijing, China. Chemistry 60, 542551.

Claisse, D. and Alzieu, C. (1993). Copper contamination as a result of antifouling paint regulations. Marine Pollut. Bull. 26, 395-397.

Cohort Software Inc. (1985). Costat User Manual, version 3 Cohort Tucson, Arizona, USA.

Contardo-Jara, V. and Wiegand, C. (2008). Biotransformation and antioxidant enzymes of Lumbriculus variegates as biomarkers of contaminated sediment exposure. Chemosphere 70, 1879-1888.

Conti, M.E., and Cecchetti, G., (2003). A biomonitoring study: trace metals in algae and mollusks from Tyrrhenian coastal areas. Environ. Res. 93, 99-112.

Dubois, M., Gilleo, K. A., Hamilton, J. K., Repers, P. A. and Smith, F. (1956). Colorimetric method for determination of sugars and related substances. Analyt. Chem. 18, 350356.

Dundar, M.S., (2006). Vanadium concentrations in settled outdoor dust particles.

Edwards, J.W., Edyvane, K.S., Boxal, V.A., Hamann, M., and Soole, K.L., (2001). Metal levels in seston and marine fish flesh near industrial and metropolitan centers in South Australia. Mar. Pollut. Bull. 42, 389-396.

Environ. Monit. Assess. 123, 345-350.

Franzle, O. (2006). Complex bioindication and environmental stress assessment. Ecol. Indic. 6, 114-136.

Fytianos, K., Evgenidou, E., and Zachariadis, G., (1999). Use of macroalgae as biological Indicators of heavy metal 
pollution in Thermaikos Gulf, Greece. Bull. Environ.Contam. Toxicol. 62, 630-637.

Gello, F. J., Olivella, T., Cruz, Pastor, M., Arenas, J., Moreno, R., Durban, R. and Gomez, J. A. (1985). A simple procedure for routine determination of aspartate aminotransferase and alanine aminotransferase with pyridoxal phosphate. Clin. Chim. Acta. 153, 241-247.

Gerofke, A., Kamp, P., and McLachlan, M.S., (2005). Bioconcentration of persistent organic pollutants in four species of marine phytoplankton. Environ. Toxcol. Chem. 24, 2908-2917.

Guijian, L., Liugen, Z., Duzgoren-Aydin, N.S., Lianfen, G., Junhua, L., and Zicheng, P., (2007). Health effects of arsenic, fluorine, and selenium from indoor burning of Chinese coal. Rev. Environ. Contam. Toxicol. 189, 89106.

Hallare, A. V., Kosmehl, T., Schulze, T., Hallert, H., Kohler, H. R., and Triebskorn, R. (2005). Assessing contamination levels of Laguna Lake sediments (Philippines) using a contact assay with zebra fish (Danio rerio) embryo. Sci. Total Environ. 347, 254-271.

Handy, R.D., and Depledge, M.H., (1999). Physiological response: their measurement and use as environmental biomarkers in ecotoxicology. Ecotoxicology 8, 329-349.

Handy, R.D., Galloway, T.S., and Depledge, M.H., (2003). A proposal for the use of biomarkers for the assessment of chronic pollution and regulatory toxicology. Ecotoxicology 12, 331-343.

ISO/IEC (1990). EN 45001 Guide 25, General Requirements for the Competence of Calibration and Testing laboratories, Geneva.

Jiang, Y., Li, X., Xu, J., Pan, C., Zhang, J. and Niu, W. (2009). Multiresidue method for the determination of 77 pesticides in wine using $\mathrm{QuEChER}_{\mathrm{s}}$ sample preparation and gas chromatography with mass spectrometry. Food Addit. Contaminat. 26 (6), 859-866.

Jones, K.C., and Voogt, P., (1999). Persistent organic pollutants $\left(\mathrm{POP}_{\mathrm{s}}\right)$ : state of the Science. Environ. Pollut. 100, 209-221.

Keegan, T.J., Farago, M.E., Thornton, I., Hong, B., Colvile, R.N., Pesch, B., Jakubis, P., and Nieuwenhuijsen, M.J., (2006). Dispersion of As and selected heavy metals around a coal-burning power station in central Slovakia. Sci. Total Environ. 358, 61-71.

Kowalewska, G., (1999). Phytoplankton the main factor responsible for transport of polynuclar aromatic hydrocarbons from water to sediments in the Southern Baltic ecosystem (extended abstract). J. Mar. Sci. 56S, 219-222.

Labra, M., Bemasconi, M., Grassi, F., De Mattia, F., Sgorbati, S., Airoldi, R., and Citterio, S., (2007). Toxic and genotoxic effects of potassium dichromate in Pseudokirchneriella subcapitata detected by microscopy and AFLP marker analysis. Aquatic Bot. 86, 229-235.

Lei, A.P., Hu, Z.L.,Wong, Y.S., and Tam, N.F.Y., (2007). Removal of Fluoranthene and pyrene by different microalgal species. Bioresour. Technol. 98, 273-280.

Lei, A.P., Wong, Y.S., and Tam, N.F.Y., (2002). Removal of pyrene by different microalgal species. Water Sci. Technol. 46, 195-201.

Lewtas, J., (2007). Air pollution combustion emissions: characterization of causative agents and mechanisms associated with cancer, reproductive, and cardiovascular effects. Mutat. Res. (E-pub ahead of print).

Liebig, M., Schmidt, G., Bontje, D., Kooi, B. W., Streck, G., Traunspurger, W., and Knacker, T., (2008). Direct and indirect effects of pollutants on algae and algivorous ciliates in an aquatic indoor microcosm. Aquatic Toxicol. 88, 102-110.

Liu, L.J.S., Box, M., Kalman, D., Kaufman, J., Koenig, J., Larson, T., Lumley, T.,

Longston, W. J. (1990). Toxic effects of metals and the incidence of metal pollution in marine ecosystem. In: Furness, R. W., Rainbow, P. S. (Eds.), Heavy metals in the Marine Environment. CRC Press. Boca Raton, FL, pp. 101-122.

Lowry, O. H., Rasebrough, N. J., Farr, A. L. and Randall, R. J. (1951). Protein measurement with the folin phenol reagent. J. Biol. Chem. 193, 265-275.

Mahler, B. J., van Metre, P. C., Bashara, T. J., Wilson, J. T., and Johns, D. A. (2005). Parking lot sealcoat: an unrecognized source of urban polycyclic aromatic hydrocarbons. Environ. Sci. Technol. 39, 5560-5566.

Moran, R. and Porath, D. (1980). Chlorophyll determination in plant tissues using $\mathrm{N}, \mathrm{N}$-dimethyl formamide. Plant Physiol. 65, 478-479

Nishikawa, K., Yamakoshi, Y., Uemura, I., and Tominaga, N., (2003). Ultrastructural changes in (Chlamydomonas acidophila) (Chlorophyta) induced by heavy metals and polyphosphate metabolism. FEMS Microbiol. Ecol. 44, 253-259.

Ohmori, M., Saino, T. and Ohmori, K. (1985). Occurrence of glutamine-2-oxaloacetic transaminase activity in the blue green algae Anabaena cylibdirca. J. Clinical Appl. Microbiol. 31, 171-176.

Papiri, S., Ciapni, C., Capodaglia, A., Collivignarelli, C., Bertanza, G., Swartling, F., Crow, M., Fantozzi, M., and Valcher, P. (2003). Field monitoring and evaluating of innovative solutions for cleaning storm water runoff. Water Sci. Technol. 47, 327-334.

Payne, J. K., and Stewart, J. R. (1955). The chemical compositions for the thallus wall of Characiosiphon rivularis (chlorophyta). Phycologia 27(1), 43-49.

Pinto, E., Sigaud-Kutner, T.C.S., Leitalo, M.A.S., Okamoto, O.K., Morse, D., and Colepicolo, P., (2003). Heavy metal 
induced oxidative stress in algae. J. Phycol. 39, 10081018.

Radwan, M.A., El-Gendy, K.S., and Gad, A.F., (2010). Biomarkers of oxidative stress in the land snail Theba pisana for assessing ecotoxicological effects of urban metal pollution. Chemosphere 79, 40-46

Rainbow, P. S. (1995). Biomonitoring of heavy metals availability in the marine environment. Marine Pollut. Bull. 8(1), 16-19.

Regoli, F., Gorbi, S., Fattorini, D., Tedesio, S., Notti, A., Machella, N., Bocchetti, R., Benedetti, M., and Piva, F., (2006). Use of the land snail Helix aspersa as sentinel organism for monitoring ecotoxicologic effects of urban pollution: an integrated approach. Environ. Health Prespect. 114, 63-69.

Sanchez-Rodriguez, I., Huerta-Diaz, M.A., Choumiline, E., Holgu'n-Quinones, O., and Zertuche-Gonza'lez, J.A., (2001). Elemental concentrations in different species of seaweeds from Loreto Bay, Baja California Sur, Mexico: implications for the geochemichal control of metals in algal tissue. Eviron. Pollut. 114, 145-160.

Sheppard, L., and Wallace, L., (2003). Exposure assessment of particulate matter for Susceptible populations in Seattle. Environ. Health Perspect. 111, 909-918.

Siripornadulsil, S., Traina, S., Verma, D.P.S., and Sayre, R.T., (2002). Molecular mechanisms of proline-mediated tolerance to toxic heavy metals in transgenic microalgae. Plant Cell 14, 2837-2847.

Todd, S.J., Cain, R.B., and Schmidt, S., (2002). Biotransformation of naphthalene and diaryl ethers by green microalgae. Biodegradation 13, 229-238.

Tremolada, P., Finizio, A., Villa, S., Gaggi, C., and Vighi, M., (2004). Quantitative interspecific chemical activity relationships of pesticides in the aquatic environment. Aquat. Toxicol. 67, 87-103.
Tripathi, B.N., Metha, S.K., Amar, A., Gaur, J.P., 2006. Oxidative stress in (Scenedesmus sp.) during short- and long-term exposure to $\mathrm{Cu}^{2+}$ and $\mathrm{Zn}^{2+}$. Chemosphere 62 , $538-544$.

Ueno, D., Watanabe, M., Subramanian, A., Tanaka, H., Fillmann, G., lam, P.K.S., Zheng, G.J., Muchtar, M., Razak, H., Prudente, M., Chung, K.H., and Tanabe, S., (2005). Global pollution monitoring of polychlorinated dibenzo- $p$-dioxins $\left(\mathrm{PCDD}_{\mathrm{s}}\right)$ furans $\left(\mathrm{PCDF}_{\mathrm{s}}\right)$ and coplanar polychlorinated biphenyls (coplanar $\mathrm{PCB}_{\mathrm{s}}$ ) using skipjack tuna as bioindicator. Environ. Pollut. 136, 303-313.

USEPA (2002). Environmental Protection Agency Health assessment document for diesel engine exhaust. Report No. EPA/600/8-90/057F, Washington, DC.

USEPA (1983). Methods for chemical analysis of water and wastewater. National technical information service, US Department of Commerce, Spring field, VA. 22161.

Van Gestel, C.A., and Van Brummelen, T.C., (1996). Incorporation of the biomarker concept in ecotoxicology calls for a redefinition of terms. Ecotoxicology 5, 217225.

Van Metre, P. C., and Mahler, B. J. (2005). Trends in hydrophobic organic contaminants in urban and reference lake sediments across the United States, 1970-2001. Environ. Sci. Technol. 39, 5567-5574.

Wang, J.S., Chou, H.N., Fan, J.J., and Chen, C.M., (1998). Uptake and transfer of high PCB concentrations from phytoplankton to aquatic biota. Chemosphere 36, 12011210.

Wei, D., Kisuno, A., Camella, T., and Urano, K., (2008). A new method for evaluating biological safety of environmental water with algae, daphnia and fish toxicity ranks. Sci. Total Environ. 371, 383-390.

Zhuang, Y., Thompson, J., Zygarlicke, C.J.,and Pavlish, J., (2004). Development of a mercury transformation model in coal combustion flue gas. Environ. Sci. Technol. 38, 5803. 


\section{الملخص العري}

\section{الدلال البيولوجية للحلب الميلة العبة Lemna minorكنموذج النلوث المنلاق الحضربة بالمبيدل}

\section{والعناdر القيلة}

خالد يلسين عبد الحليم

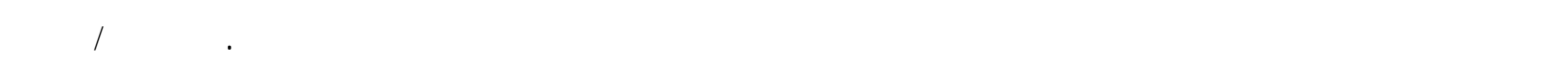

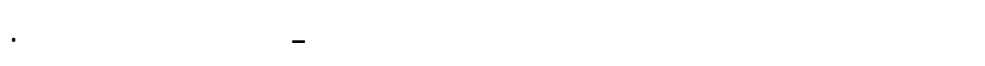

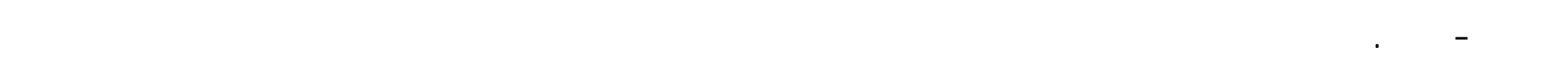

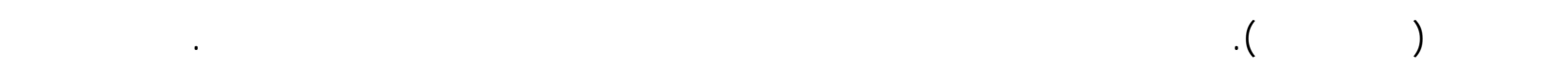

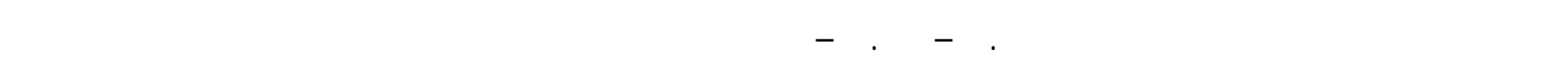

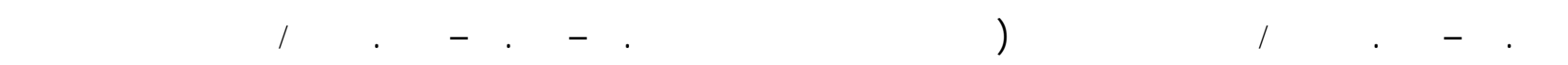

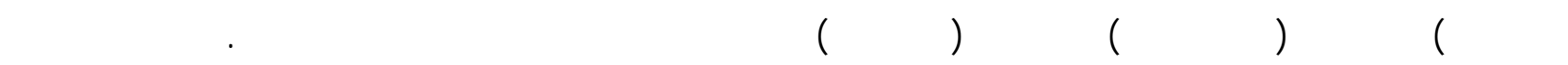

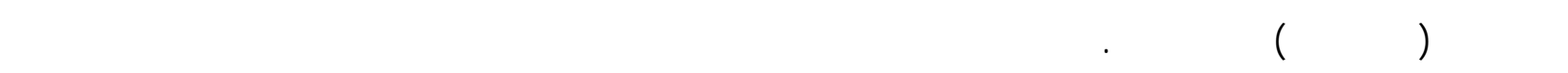

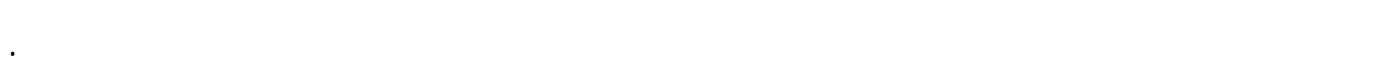

